Comments on Aboriginal Ceramic Sherds from Sites at the Proposed Lower Bois d'Arc Creek Reservoir, Fannin County, Texas

Timothy K. Perttula

Heritage Research Center, Stephen F. Austin State University

Follow this and additional works at: https://scholarworks.sfasu.edu/ita

Part of the American Material Culture Commons, Archaeological Anthropology Commons, Environmental Studies Commons, Other American Studies Commons, Other Arts and Humanities Commons, Other History of Art, Architecture, and Archaeology Commons, and the United States History Commons

Tell us how this article helped you.

This Article is brought to you for free and open access by the Center for Regional Heritage Research at SFA ScholarWorks. It has been accepted for inclusion in Index of Texas Archaeology: Open Access Gray Literature from the Lone Star State by an authorized editor of SFA ScholarWorks. For more information, please contact cdsscholarworks@sfasu.edu. 
Comments on Aboriginal Ceramic Sherds from Sites at the Proposed Lower Bois d'Arc Creek Reservoir, Fannin County, Texas

\section{Creative Commons License}

\section{(c) (1) \&}

This work is licensed under a Creative Commons Attribution-NonCommercial 4.0 International License 


\title{
Comments on Aboriginal Ceramic Sherds from Sites at the Proposed Lower Bois d'Arc Creek Reservoir, Fannin County, Texas
}

\author{
Timothy K. Perttula
}

\section{Introduction}

Twelve of the 28 prehistoric archaeological sites recorded by Davis et al. (2014) at the proposed Lower Bois d'Arc Creek Reservoir in Fannin County have aboriginal ceramic sherds; the reservoir is on Bois d'Arc Creek, a northward-flowing tributary to the Red River (Figure 1). Aboriginal ceramic sherds are not at all common in these sites, as only 123 sherds were recovered from all 12 of the survey sites. The ceramics are found on both Woodland and ancestral Caddo sites, but because the majority of the sherds are undecorated, only general chronological or cultural affiliation information on the ceramics were provided by Davis et al. (2014). I offer comments on the character of the ceramics, based on the descriptions of temper, thickness, and decoration in Davis et al. (2014).

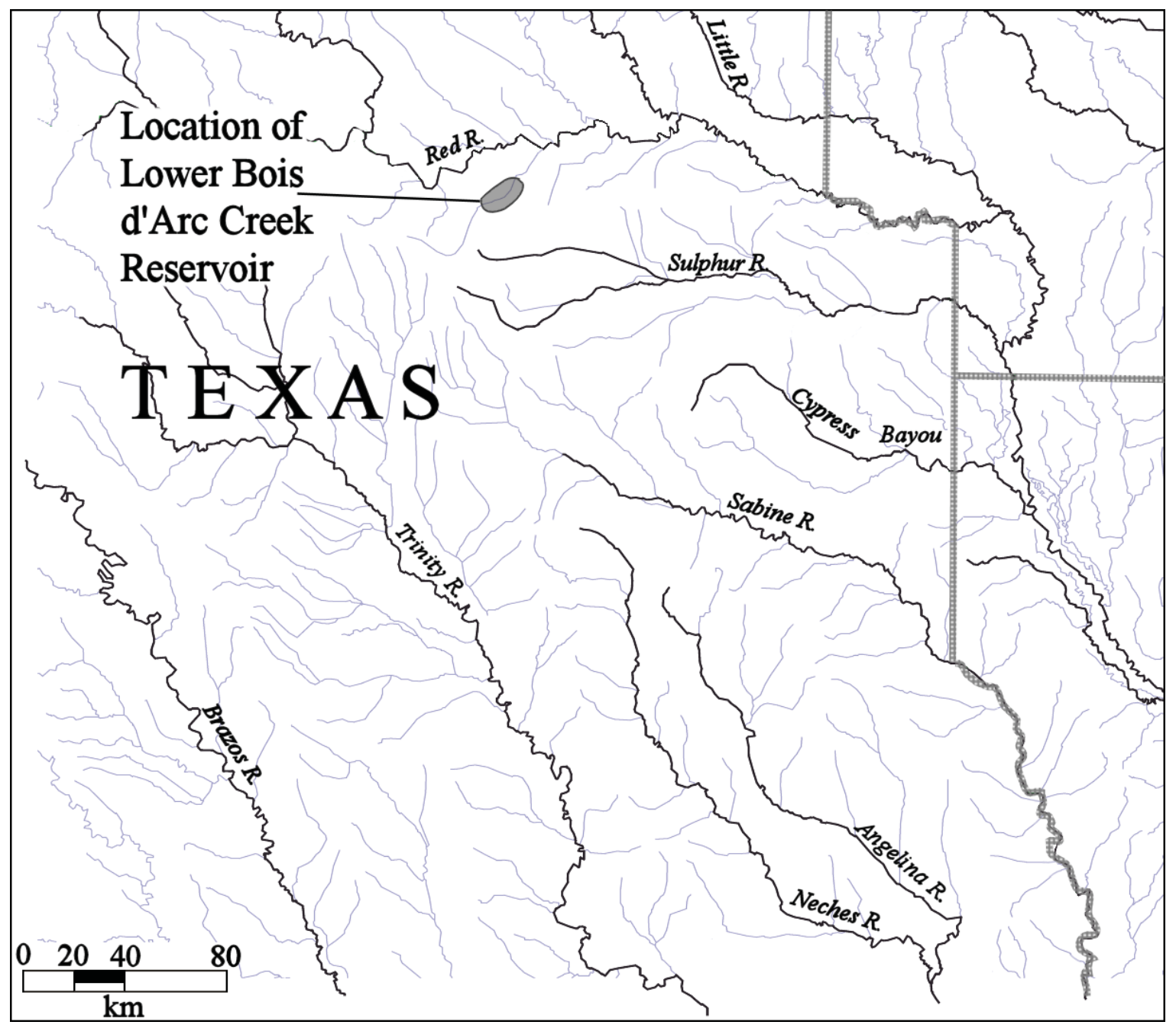

Figure 1. Location of the proposed Lower Bois d'Arc Creek Reservoir in East Texas. 


\section{Ceramic Sherds from Sites}

The one ceramic sherd recovered from 41FN110 is described as a plain laminated body sherd. Davis et al. (2014:143) consider "lamination indicative of Woodland ceramics." Specifically, laminated, non-tempered sherds represent early Woodland Tchefuncte pottery, likely dating from ca. 500-100 B.C. (Brown 1998; Hays and Weinstein 2010; Aten and Bollich 2011). If the identification of the laminated paste on the 41FN110 sherd is accurate, this site is only the third site in East Texas where Tchefuncte pottery has been found (see Ellis 2013); the other two sites are the well-known Resch site (41HS16) in the Sabine River basin in Harrison County, Texas (Webb et al. 1969), and the Mike Myers site (41CE481) in the Neches River basin (Perttula and Stingley 2017). Tchefuncte culture pottery has been recovered from the Louisiana Gulf Coast, in the Ouachita and Mississippi river basins in Mississippi, Louisiana, and southeast Arkansas, and in the Sabine Lake area of coastal Texas and Louisiana (Hays and Weinstein 2010; Aten and Bollich 2011), more than $400 \mathrm{~km}$ south and southeast of 41FN110.

In the case of 41FN111 and 41FN114, the three plain body sherds have grog or grog-bone temper; sand is described as a temper in both sherds, but it is more likely that the sherds are from vessels made with a naturally sandy clay. The body walls of two of the sherds could be measured, and their thickness ranges from 8.8-9.3 mm. On that basis, Davis et al. $(2014: 145,153)$ speculate that the sherds "likely date to the Woodland or Early Caddo periods." If the thickness measurements on these sherds is accurate, then it is most likely that they are from Woodland period Williams Plain vessels. Williams Plain is a thickwalled vessel form (Schambach 1998, 2002), and ancestral Caddo ceramic vessels tend to have much thinner vessel walls (Perttula 2013:201-202). Recent analysis of a sample of grog-tempered Williams Plain sherds from the Woodland period component at the Snipes site (41CS8) (Sitters and Perttula 2017) indicate that body sherds range from $8.7-11.9 \mathrm{~mm}$ in thickness, the plain sherds from 41FN111 and 41FN114 fall within that range; rim sherds range from 8.3-10.6 mm; and base sherds range from 11.3$15.2 \mathrm{~mm}$ thick.

At 41FN118, one plain grog-bone-tempered body sherd that is $9.4 \mathrm{~mm}$ thick is likely from a Woodland period Williams Plain vessel. The other sherd, tempered with grog and hematite and with $6.9 \mathrm{~mm}$ thick body walls, is described as "possibly slipped." Davis et al. (2014:164) conclude that the ceramics are "Woodland to Early Caddo in age." It is more likely that the ceramics represent two different periods of use, a Woodland period use marked by a Williams Plain sherd followed by a use during the Middle Caddo period by ancestral Caddo peoples who made red-slipped vessels. Red-slipped fine wares (bowls, carinated bowls, and an occasional bottle) are a common part of ancestral Caddo ceramic assemblages in several parts of East Texas, most notably in sites in the middle Red River, the Big Cypress Creek basin, the upper Sulphur and Sabine River basins, and the middle Sabine River basin (Perttula 2015:Figure 3). Red-slipped sherds are typically of Middle Caddo period age (ca. A.D. 12001400) and are relatively abundant at sites such as Jamestown (41SM54), A. C. Gibson (41WD1), Sam Kaufman (41RR16), A. C. Mackin (41LR31), Harling (41FN1), and Sanders (41LR2) on the Sabine and Red rivers, respectively, several sites in the upper Sulphur River basin (41DT54 and 41DT63), and 41TT110 on Big Cypress Creek (see Perttula 2015:Table 1).

Seven plain body sherds were recovered from 41FN119 in shovel tests and one test pit. The one described sherd (Davis et al. 2014:166) is $5.7 \mathrm{~mm}$ thick and has a grog-sand temper. Davis et al. (2014:166) suggest the sherd "likely dates to the Early to Middle Caddo periods," but offer no reasons why the sherd dates to this ca. 400 year period (ca. A.D. 1000-1400).

The largest assemblage of aboriginal ceramic sherds from any site at the proposed Lower Bois d'Arc Creek Reservoir are the 75 plain sherds from 41FN120: 74 body sherds and one rim sherd. These sherds were tempered with grog $(n=25)$, grog-bone $(n=22)$, grog-hematite $(n=4)$, grog-bone-hematite $(n=1)$, grog-hematite-sand $(n=1)$, and shell $(n=1)$. Davis et al. (2014:173), however, indicate that seven of the sherds have a red slip on their exterior surface; thus, since slipping is a decorative treatment, only 68 
sherds from the site are plain. Based on thickness measurements of the sherds, Davis et al. (2014:178) suggest that the ceramics from 41FN120 date from the Woodland period to the Early Caddo period.

As with the sherds from 41FN118, the red-slipped sherds from 41FN120 are likely from a Middle Caddo period component, as this was the period of time when non-shell-tempered red-slipped sherds (i.e., Sanders Slipped, see Perttula et al. 2016) were relatively abundant in middle Red River ceramic assemblages. Certainly the one shell-tempered sherd is from a post-A.D. 1400 Caddo occupation, probably contemporaneous with the McCurtain phase downstream in the Mound Prairie area of the Red River. Davis et al. (2014) suggest that the tempers represented at the site are consistent with WoodlandEarly Caddo assemblages, but in fact they are also consistent with a Middle Caddo period occupation; the red-slipped sherds lend credence to this temporal affiliation of much of the 41FN120 ceramics. Davis et al. (2014) do note that 29 percent of the sherds (without specifying which sherds) are 8-9 mm thick, and it is reasonable to conclude that they are from Woodland period Williams Plain vessels. This in turn also suggests that 71 percent of the sherds are from ancestral Caddo ceramic vessels that are just as likely to date to the Middle Caddo period as they do the Early Caddo period.

Twenty-four plain body sherds tempered with grog, grog-bone, grog-bone-hematite, grog-bone-sand, and grog-hematite-sand from 41FN122 range from 8.5-9.6 mm thick, and are probably from Woodland period Williams Plain vessels. The one plain rim is not from a Williams Plain vessel, as it is only $6.5 \mathrm{~mm}$ thick; it is most likely from an ancestral Caddo vessel. Davis et al. (2014:186) suggest that the ceramics from 41FN122 have "tempers dominated by grog and bone... attributed to the Woodland and Early Caddo time periods."

Only one plain grog-tempered sherd was recovered from 41FN123; whether it is a body or base sherd is not noted by Davis et al. (2014). That the sherd is $9.0 \mathrm{~mm}$ thick suggests it is from a Williams Plain vessel, and Davis et al. (2014) argue that the sherd could be Woodland or Early Caddo in age; the former seems more likely. The same can be said for the one plain sherd from 41FN125 that is $10.1 \mathrm{~mm}$ thick; again, however, Davis et al. (2014) do not indicate whether the sherd is a body or base sherd.

At 41FN134, one plain body sherd tempered with grog-bone-hematite is $7.9 \mathrm{~mm}$ thick, and likely is from a vessel made by an ancestral Caddo potter. The second sherd, also tempered with grog-bonehematite-has an "eroded red slip on the exterior surface with an incised mark" (Davis et al. 2014:222), and is also from a Caddo vessel. The photograph of the vessel by Davis et al. (2014:Figure 206) shows no visible decoration, and in any case, if there is a decoration on the red-slipped sherd, it would be engraved, not incised. Incised and red-slipped sherds are not a feature of East Texas Caddo ceramics, and it is likely that the 41FN134 sherd is actually from a red-slipped Sanders Engraved vessel. Such vessels were made during the Middle Caddo period in the middle Red River basin (Perttula 2013, 2015).

Two plain grog-tempered sherdlets have been recovered from 41FN136; they are tempered with grog-sand and grog-hematite-sand. No supporting evidence is offered by Davis et al. (2014:225) to corroborate their speculation that the "sherds are likely Woodland to Middle Caddo in age." That conclusion could be offered for every grog-tempered sherd found in the middle Red River basin, but is not one that can be reasonably and independently evaluated.

The last site with ceramic sherds at the proposed Lower Bois d'Arc Creek Reservoir is 41FN151. Davis et al. (2014:258 and Figure 242) identify the sherds as Williams Plain, but offer no temper or thickness values for any of the sherds to evaluate that finding. Furthermore, based on the limited data presented by Davis et al. (2014:Table 34) on the provenience of the ceramic sherds recovered at the site - namely five sherds between $10-40$ and $60-70 \mathrm{~cm}$ bs in three different shovel tests - it is not possible to determine if any of the sherds are associated with either of the two radiocarbon dates obtained from the archaeological deposits at 41FN151: A.D. 710-750 and A.D. 770-890 (2 sigma calibrated, 50-60 $\mathrm{cm}$ bs in ST 44) and A.D. 900-920 and A.D. 940-1020 (2 sigma calibrated, 110-120 $\mathrm{cm}$ bs in BHT 12). 


\section{Conclusions}

In virtually every case where a site at the proposed Lower Bois d'Arc Creek Reservoir had aboriginal ceramics tempered with grog or other aplastics, Davis et al. (2014) concluded that the sherds likely dated to the Woodland (ca. 500 B.C.-A.D. 800) or Early Caddo periods (ca. A.D. 800-1200). Nevertheless, they offered no good reasons why the ceramics should date from this long time range, or could not date after ca. A.D. 1200. The evidence presented by Davis et al. (2014) points to the use of several of the sites after ca. A.D. 1200, and in one case even after ca. A.D. 1400.

The fact that one sherd from 41FN110 identified as having a laminated paste was not followed by the likely conclusion that the sherd is from an early Woodland Tchefuncte pottery vessel, probably the earliest ceramics in the Bois d'Arc Creek basin, makes no sense. Three other sites have sherds from grog-tempered red-slipped vessels - most likely from Sanders Slipped vessels - and these likely occur in Middle Caddo period components at the sites, not during the Early Caddo period; the Middle Caddo period in East Texas was the principal time when grog-tempered red-slipped ceramic vessels were made in the region. Finally, the one shell-tempered sherd from 41FN120 is from a post-A.D. 1400 ceramic vessel.

\section{References Cited}

Aten, L. E. and C. N. Bollich

2011 Early Ceramic Sites of the Sabine Lake Area, Coastal Texas and Louisiana. Studies in Archeology 43. Texas Archeological Research Laboratory, The University of Texas at Austin.

Brown, I. W.

1998 Decorated Pottery of the Lower Mississippi Valley: A Sorting Manual. Mississippi Archaeological Association and Mississippi Department of Archives and History, Jackson.

Davis, C. S., S. A. Skinner, and M. A. Hall

2014 Archaeological Survey of the Proposed Lower Bois d'Arc Creek Reservoir, Fannin County, Texas. Cultural Resources Report 2014-60. AR Consultants, Dallas.

Ellis, L. W.

2013 Woodland Ceramics in East Texas and a Case Study of Mill Creek Culture Ceramics. Bulletin of the Texas Archeological Society 84:137-180.

Hays, C. T. and R. A. Weinstein

2010 Tchefuncte and Early Woodland. In Archaeology of Louisiana, edited by M. A. Rees, pp. 97-119. Louisiana State University Press, Baton Rouge.

Perttula, T. K.

2013 Caddo Ceramics in East Texas. Bulletin of the Texas Archeological Society 84:181-212.

2015 East Texas Caddo Ceramic Sherd Database. Journal of Northeast Texas Archaeology 51:1-46.

Perttula, T. K. and K. Stingley

2017 Archaeological Investigations at the Mike Myers Site (41CE481) on Bowles Creek in Cherokee County, Texas. Journal of Northeast Texas Archaeology 74:47-80.

Perttula, T. K., M. Walters, and B. Nelson

2016 Caddo Ceramic Vessels from the T. M. Sanders Site (41LR2) on the Red River in Lamar County, Texas. Special Publication No. 41. Friends of Northeast Texas Archaeology, Austin and Pittsburg. 
Schambach, F. F.

1998 Pre-Caddoan Cultures in the Trans-Mississippi South: A Beginning Sequence. Research Series No. 53. Arkansas Archeological Survey, Fayetteville.

2002 Fourche Maline: A Woodland Period Culture of the Trans-Mississippi South. In The Woodland Southeast, edited by D. G. Anderson and R. C. Mainfort, Jr., pp. 91-112. University of Alabama Press, Tuscaloosa.

Sitters, J. A. and T. K. Perttula

2017 Another Look at the Snipes Site (41CS8) on the Sulphur River, Cass County, Texas. Journal of Northeast Texas Archaeology 75, this volume.

Webb, C. H., F. E. Murphey, W. G. Ellis, and H. R. Green

1969 The Resch Site, 41HS16, Harrison County, Texas. Bulletin of the Texas Archeological Society 40:3106. 